\title{
Use of Plant Growth Regulators for Improving Fruit Production in Sub Tropical Crops
}

\author{
Shilpy Kumari", Parshant Bakshi, Akash Sharma, V.K. Wali, \\ Amit Jasrotia and Simrandeep Kour
}

Division of Fruit Science, Faculty of Agriculture, SKUAST-J, India

*Corresponding author

\section{A B S T R A C T}

Keywords

Plant growth regulators, Growth, Fruit, Yield

Article Info

Accepted:

07 February 2018

Available Online:

10 March 2018

Plant growth regulator or phytohormone may be defined as an organic substance produced naturally in plants controlling growth and other functions at a site remote from its place of production in minute quantities. Plant growth regulators include auxins, gibberellins, cytokinins, ethylene, growth retardants and growth inhibitors. The production of poor quality fruits is a matter of common experience. It would be therefore worthwhile to improve the yield and quality of fruit crops by foliar application of plant growth regulators. The use of growth regulators has become an important component of agro-technical procedures for most of the cultivated plants and especially for fruit plants. So far in fruit crops, excessive fruit drop can be controlled by the exogenous application of plant growth regulators. The auxin and gibberellins are widely used to control the fruit drop and to improve the quality of fruit. Ontogenic development from fruit set to fruit ripening and final reach to customer, several agents are responsible for elimination of some fruits from fruit set to final maturity. In this review, we focus on the role of plant growth regulators in subtropical fruit production.

\section{Introduction}

Plant growth regulators or phytohormones are organic substances produced naturally in higher plants, controlling growth or other physiological functions at a site remote from its place of production and active in minute amounts. Thimmann proposed the term Phyto hormone as these hormones are synthesized in plants. Plant growth regulators include auxins, gibberellins, cytokinins, ethylene, growth retardants and growth inhibitors. Auxins are the hormones first discovered in plants and later gibberellins and cytokinins were also discovered. During the last 50 years considerable research work has been done in the country on various aspects such as varieties, propagation, irrigation, training and pruning etc. to increase the yield and quality of guava fruits. The production of poor quality fruits is a matter of common experience. It would be therefore worthwhile to improve the yield and quality of fruit crops by foliar application of plant growth regulators. The use of plant growth regulators has assumed an integral part of modern crop husbandry for increasing production of quality fruits. The plant hormones or 
regulators are the organic chemical compounds, which modify or regulate physiological processes in an appreciable measure in the plant when used in small concentration. They are readily absorbed and move rapidly through the tissues, when applied to different plant parts. These chemicals are specific in their action. In other words, plant growth regulators are organic substances (other than nutrients), which in small amount promote, inhibit or otherwise modify any physiological process in plants. Thus the use of plant growth regulators has resulted in some outstanding achievements in several fruit crops with respect to growth, yield and quality. Physiological responses that are currently regulated /influenced by PBR's are- Promotion of feathering and branching, Increase flower bud formation inhibit flower bud formation, Thinning by promotion of fruit/flower abscission, Retard pre-harvest drop, Improve fruit finish, Improve fruit shape, Vegetative growth control, Increase fruit set, Increase fruit red colour, Advance fruit ripening, Delay fruit ripening, Enhance rooting, Suppress growth of water sprouts, Improve stress tolerance. Lawes and Woolley (2001) examined the commercial use of plant growth regulators to regulate fruit development. Fruit trees are considered high value crops and even small modifications in production efficiency, product quality or enhanced cosmetic appeal have the potential to significantly increase product value.

Use of PBRs is a unique fact of biotechnology and a new approach of manipulating plant biological activities for enhancing growth, yield, quality, nutritive value and also to reduce biotic and abiotic stress in plants. PBRs like jasmonic acid, its volatile ester methyl jasmonate (MJ), and other derivatives, collectively known as jasmonates (JA's), are ubiquitous signalling molecules which mediate plant responses to environmental stress such as wounding, and insect and pathogen attack (Wasternack, 2007).Though bio-regulators are commonly used to improve plant growth, development, pathogenic defense and productivity, the molecular mechanisms of their effects still remain to be fully elucidated.

\section{Class of plant growth regulators}

Auxins: IAA, NAA, IBA, 2-4D, 4- CPA

Gibberellins: GA3

Cytokinins: Kinetin, Zeatin

Ethylene: Ethereal

Abscissic acid: Dormins, Phaseic Acid

Phenolic substances: Coumarin

Flowering hormones: Florigin, Anthesin, Vernalin

Natural substances: Vitamins, Phytochrome Tranmatic

Synthetic substances: Synthetic Auxins, Synthetic Cytokinins

Growth inhibitors: AMO-1618, Phosphon-D, Cycosel, B-999.

\section{Functions of some plant growth regulators}

\section{Auxin}

NAA is a synthetic auxin plant hormone that is routinely used for the vegetative propagation of plants from stem and cutting. The effect of NAA on plant growth is greatly dependent on the time of admission and concentration. NAA has been shown to greatly increase cellulose fiber formation in plants. In majority of fruit plants fruit drop is controlled by spraying of NAA in different 
fruit crops in different concentration. It is applied after blossom fertilization.

\section{Gibberellins}

Gibberellins control fruit development in various ways and at different developmental stages. Fruit development is a complex and tightly regulated process. Growing fruits are very active metabolically and act as strong sinks for nutrients with hormones possibly modulating the process (Brenner and Cheikh, 1995). The development of a fruit can be separated into phases that include prepollination, pollination, fertilization and fruit set, post fruit set, ripening and senescence. The successful fertilization of the ovule is followed by cell division and cell expansion resulting in the growth of the fruit. Gibberellins are known to influence both cell division and cell enlargement (Adams et al., 1975).

\section{Cytokinins}

Cytokinins act in cell division, cell enlargement, senescence, and transport of amino acids in plants.

\section{2,4-D}

Endogenous hormones and their balance play a modulating role in the mobilization of nutrients to the developing organs and can influence the longevity of a bud. The dependence of abscission relative to the endogenous content of auxins has been proven by exogeneous application of 2,4-D or NAA, as the transportation of auxins by the plant lasts for a long time without ethylene appearing to affect it.

\section{Paclobutrazol}

Paclobutrazol is probably the most widely used PGR in the production of fruit crops because of its wide range of efficacy and moderate- to long-lasting response. Applications of paclobutrazol, particularly when delivered as a spray, delay flower development and reduce flower size. Paclobutrazol is absorbed by roots and stems, and to a lesser extent, by leaves. Therefore, it can be applied as a spray, sprench, drench, or bulb or young-plant dip. Sprays are more effective when they penetrate plant canopies so that there is contact with stems. The postharvest application of a small amount of paclobutrazol to the soil significantly promotes flowering and fruiting in the following year. Therefore, early and proactive applications are strongly recommended, and late applications should generally be used as a last resort.

\section{Ethylene}

Ethylene is a naturally occurring plant growth substance that has numerous effects on the growth, development and storage life of many fruits crops. Harvested fruits may be intentionally or unintentionally exposed to biologically active levels of ethylene and both endogenous and exogenous sources of ethylene contribute to its biological activity. Ethylene synthesis and sensitivity are enhanced during certain stages of plant development, as well as by a number of biotic and abiotic stresses

\section{Use of plant growth regulators in subtropical fruit crops}

Brahmachari et al., (1995) reported that application of ethrel at 25 or $50 \mathrm{ppm}$ in guava enhanced fruit set percentage, weight, quality of fruit while, reduced number and weight of seeds thereby increased pulp / seed ratio.

Medeiros et al., (2000) found that application of 2,4-D@10 ppm has given the best preharvest fruit drop control in 'Hamlin' orange. 
Ghora et al., (2000) conducted an experiment on effect of growth retardants (CCC, daminozide and paclobutrazol) on growth and development under plastic green house condition and found that application of 500 ppm CCC enhanced anthesis and fruit ripening by about 10 days. In an experiment on effect of growth substances on flowering and fruiting characters of 'Sardar' guava. PBRs such as NAA, $\mathrm{GA}_{3}$, and CPPU sprayed to 'Arumani' mango trees at 14 days after blooming which results that CPPU (1-(2chloro-4-pyridyl)-3-phenylurea) at $10 \mathrm{ppm}$, gave the best result in increasing fruit retention, number of fruit per cluster, fruit weight, volume and leaf area (Notodimedjo, 2000).

Ingle et al., (2001) revealed that foliar application of $\mathrm{GA}_{3} @ 25 \mathrm{ppm}$ increased the fruit weight, volume, TSS, ascorbic acid, peel and yield over control in 'Nagpur' mandarin. Eel Yadav et al., (2001) concluded that fruit weight, organoleptic rating, TSS, ascorbic acid and total sugar content of guava fruits increased significantly over control by the application of NAA @ 20 to 60 ppm and decreased fruit pressure $\left(\mathrm{kg} / \mathrm{cm}^{2}\right)$ significantly to make it more acceptable. Application of paclobutrazol $10 \mathrm{~g} /$ tree in mango resulted reduced tree height $(21.20 \%)$, tree volume $(33.1 \%)$ and mean shoot length $(48.2 \%)$. This response was attributed to GA - inhibitory activity of paclobutrazol (Murti et al., 2001).

Singh et al., (2001) reported that the effects of chemicals on fruit drop, yield, and quality of ber (Ziziphus mauritiana) cv. Umran. NAA, 2, 4-D, and $\mathrm{GA}_{3}$ (each at 15, 30 and 60 ppm concentrations) were sprayed on trees. NAA treatments were best in improving the yield and quality of Umran fruits. The highest yield $(166 \mathrm{~kg} /$ tree $)$ and total soluble solid content $(13.6 \%)$ as well as the largest fruits $(4.62 \mathrm{~cm}$ in length and $3.0 \mathrm{~cm}$ in diameter) were recorded for NAA (60 ppm). NAA at $30 \mathrm{ppm}$ resulted in the lowest acidity $(0.24 \%)$ and highest ascorbic acid (109 mg/100 g pulp) contents. $\mathrm{GA}_{3}$ treatments considerably reduced fruit drop, increased fruit set, and improved the fruit yield of ber. $\mathrm{GA}_{3}$ at 60 ppm recorded the lowest fruit drop (75\%) and highest fruit set (16.6\%) and yield (164 $\mathrm{kg} /$ tree).

Yeshayahu et al., (2001) stated that spray of 300 ppm NAA increased fruit size in 'Myovaze Satsuma' mandarin and NAA also thinned the fruit-lets and decreased total yield. Ghawade et al., (2002) studied of physico chemical characters of the fruits in Nagpur mandarin located at different sides of trees and found that, fruits located inside the tree contain less TSS and acid whereas, those exposed in the sun had more total soluble solids, ascorbic acid and rapid colour development resulting in early ripening. Vijayalakshmi and Srinivasan, 2002 notified that soil application with $10 \mathrm{ml}$ paclobutrazol resulted in the increase of panicle length, number of branches per panicle, number of hermaphrodite and male flowers in mango.

Kim et al., (2003) application in Satsuma mandarin with $\mathrm{GA}_{3}$ at 0, 25, 50 and 100 ppm and reported considerably decreased the number of flowers and increased the number of vegetative shoots. Fruit set rate showed an increasing tendency as the $\mathrm{GA}_{3}$ level increased and increase fruit size. Baghel and Tiwari (2003) concluded that spray of 6 per cent urea and 150 ppm NAA in mango found superior for increasing the total number of flowers/panicle and percentage of hermaphrodite flowers. However, maximum flowering and fruiting and number of fruits/tree was recorded under combined application of 4 per cent urea and $150 \mathrm{ppm}$ NAA. Use of plant bio-regulators for induction or delaying in flowering in different fruit crops is differ as per the purpose of users so, it is necessary to keep in mind using of 
plant bio regulators as per it responses with different concentrations for induction of flowering. In many woody plants including fruits GA inhibits flower formation. In these cases growth retardants viz., paclobutrazol, SADH which inhibits GA biosynthesis are used to promote flowering in mango e.g. Application of paclobutrazol helps in restricting the vegetative phase and increasing the reproductive phase of mango (Baghel et al., 2004). Kher et al., (2005) reported that the spray of $\mathrm{GA}_{3}$ was found to be most effective in increasing the weight and specific gravity and decreased total acid content of guava fruits. Whereas, maximum reducing sugar and ascorbic acid content were recorded with NAA 80 ppm and $\mathrm{GA}_{3} 60$ ppm, respectively in cv. Sardar.

Greenberg et al., (2006) observed the effect of spray of NAA $300 \mathrm{ppm}$ on yield, fruit size, fruit quality, fruit splitting and the incidence of creasing in 'Nova' mandarin. The early NAA spray, thinned fruit lets, increased fruit size, decreased splitting to 30 per cent, decreased the incidence of creasing to 28 per cent compared to 36 per cent in the control, and had no effect on the yield. Greenberg et al., (2006) also observed the effect of spray with 2,4-D, $40 \mathrm{ppm}$ on yield, fruit size, fruit quality, fruit splitting and the incidence of creasing in 'Nova' mandarin and found that early spray of 2,4-D decreased fruit splitting to 25 per cent, increased yield to $50 \mathrm{~kg} /$ tree compared to $37 \mathrm{~kg} /$ tree in the control, increased fruit size and had no effect on the incidence of creasing.

Modesto et al., (2006) studied the effect of foliar sprays of $\mathrm{GA}_{3}$ at $0,5,10,15$ and $20 \mathrm{ppm}$ in 'Ponkan' mandarin and reported, delay in fruit harvesting, which was induced by the physiological effect of $\mathrm{GA}_{3}$. Prasad et al., (2006) observed that foliar application of NAA at 10, 20, 30 and $40 \mathrm{ppm}, 2,4-\mathrm{T}$ at 10, 20, 30 and 40 ppm, 2, 4, 5-T at 20, 40, 60 and
80 ppm, GA3 at 50, 100, 150 and 200 ppm improved the flowering behavior, fruit set and fruit retention of mango. Crop regulation in guava 'Sardar' by reducing of crop load of rainy season crop through foliar application of NAA (600 ppm) produced maximum winter crop yield (Suleman et al., 2006).

Harhash and Al-obeed (2007) studied effect of different concentrations of NAA in Barhee and Shahi date palm cultivars on the bunch weight and both physical and chemical properties during two successive year 2005 and 2006. The observed that NAA $(0,50$, 100,150 and $200 \mathrm{ppm}$ ) applications on fruits of Barhee and Shahi cultivar.10 weeks after fruit set at depressed period resulted that application of 150 ppm NAA increased the yield and improve fruit quality. Saleem et al., (2008) observed that application of GA3 in 'Blood Red' sweet orange has reduced fruit weight, diameter, peel thickness and peel quality, improved juice content (\%), pulp (\%), reducing sugar, non-reducing sugar, total sugar, TSS (\%) and Vitamin C.

Nawaz et al., (2008) studied the effect of foliar sprays of NAA @ 10, 15 and 20 ppm in Kinnow mandarin and maximum Vitamin $C$ contents $(45.30 \mathrm{mg} / 100 \mathrm{~g})$ was found in 15 ppm NAA. Shinde et al., (2008) reported that application of triacontanol at 300, 500, and $700 \mathrm{ppm}$ at flowering, pea and marble stage of fruit development in mango cv. Parbhani Bhusan and showed that spray of $700 \mathrm{ppm}$ triacontanol significantly given maximum length $(10.91 \mathrm{~cm})$, breath $(8.91 \mathrm{~cm})$, volume (336.58 cm3), weight (330.41 g), mesocarp $(69.92 \%)$ and lowest proportion of endocarp (12.00\%). Iqbal et al., (2009) applied with 15, $30,45,60,75$ and 90 ppm NAA through foliar spray and reported that $45 \mathrm{ppm}$ spray reduced pre-harvest fruit drop, increased yield, pulp/acid ratio (11.31), TSS (11\%), total sugar $(7.45 \%)$, acidity and ascorbic acid in guava. Brar (2010) reported that 
paclobutrazol @ 500 ppm having highest growth retardation effect in guava. Sharma and Belsare, (2011) reported that foliar application of boron at 0.2 per cent and CPPU @ 10 ppm reduced extent of fruit cracking and increased fruit size, fruit weight and juice contents were noticed with CPPU @ 5 ppm in pomegranate cultivar ' $\mathrm{G}-137$ '.

Amiri et al., (2012) applied 0, 10, 30 and 60 ppm 2,4-D through foliar spray and found that 60 ppm spray reduced pre harvest drop compare to control, significantly decreased percent of small, very small fruit size and increase large and marketable fruit size in Satsuma mandarin.

Ghosh et al., (2012) application of different doses of NAA @ 15, 20, 25 and 30ppm and observed that sprayed of NAA at 15 ppm was the most effective in reducing the fruit drop at different months after fruit set which resulted in doubling of fruit production as compared to control and improved fruit size in sweet orange.

Kacha et al., (2012) studied that application of NAA in phalsa and recorded that spray of 200 ppm NAA resulted maximum height of bush $(177.33 \mathrm{~cm})$ and length of shoot $(99.17$ $\mathrm{cm})$.

Kumar et al., (2012) observed that the application of GA3 in strawberry at $80 \mathrm{ppm}$ improved vegetative growth, runner production, ascorbic acid and acidity. Reddy and Prasad (2012) reported that the spray with $\mathrm{GA}_{3} 75 \mathrm{ppm}$ has increased fruit size and yield in pomegranate cv. Ganesh. Khalid et al., (2012) working in young 'Kinnow' mandarin found that the spray of gibberellic acid 10 ppm at fruit setting stage and their effect on fruit quality was evaluated immediately after harvest. The PGRs alone had significant influence on juice mass (\%), rag mass (\%), ascorbic acid (mg $100 \mathrm{~mL}-1)$ and reducing sugars (\%) whereas, rind mass (\%), TSS, titratable acidity (TA), TSS:TA and total sugars (\%) were not affected by PGRs applications. Painkra et al., (2012) reported that the effect of foliar application of NAA $(10,20,30$ and $40 \mathrm{ppm}), 2,4-\mathrm{D}(5,10,15$ and $20 \mathrm{ppm})$ and GA3 (50, 100, 150 and 200 ppm) on fruit retention, yield and quality characters of Langra mango. Fruit retention was maximum with NAA $40 \mathrm{ppm}$. Length, width and weight of fruit and pulp were maximum with NAA 40 ppm. GA $_{3} 150$ ppm recorded maximum TSS while 2; 4-D 10 ppm recorded minimum acidity. The maximum yield $(28.90 \mathrm{~kg})$ per plant was harvested under NAA (40 ppm).

Reddy and Prasad (2012) reported that application of 2,4-D at 20, 30 and 40 ppm three times starting at full bloom and, subsequently, at 45 and 90 days after fruit set in pomegranate cv. Ganesh, has resulted significantly increased fruit size in length, breadth and volume and higher fruit weight (262.23g), higher aril percent and maximum number of fruits (64.00) which resulted in highest fruit yield of $16.78 \mathrm{~kg} /$ plant.

Ashraf et al., (2013) conducted an experiment to see the influence of 2,4-D in Kinnow and observed improved fruit weight, more number of fruits per plant, juice percentage, total soluble solids (TSS), ascorbic acid content, acidity, TSS/acid ratio, and reduced the fruit drop. Goswami et al., (2013) studied the effect of plant growth substances on quality components were carried out on pomegranate. Total 15 treatments were used, out of which only ethrel 200 ppm treatment was found effective on all the five quality traits. Application of ethrel $200 \mathrm{ppm}$ has improved the TSS $(17.18 \%)$, reducing sugar $(10.83 \%)$, non-reducing sugar $(1.68 \%)$, total sugar $(12.50 \%)$, and ascorbic acid content (14.85\%). Choudhary et al.,(2014) study the individual effect of plant growth regulators on 
growth and yield of Nagpur mandarin (Citrus reticulata Blanco.) and he revealed that application of $\mathrm{GA}_{3} @ 100$ ppm showed superior results with respect to per cent increase in plant spread $(20.59 \%)$ and crown volume $(38.42 \%)$ and maximum number of fruit per tree, fruit retention per cent and yield per plant and per hectare was recorded with the spray of $30 \mathrm{ppm}$ 2,4-D. Ye-mao et al., (2013) reported that brassinosteroides plays an important role in strawberry fruit ripening, and may be involved in early fruit development. Ahmad et al., (2013) found preharvest spray of $\mathrm{SA}$ at $8 \mathrm{mM}$ effective to increase the fruit firmness, soluble solid content, titratable acidity, sugars and organic acids of 'Lane Late' Sweet Orange (Citrus sinensis L.) during cold storage.

Anawal et al., (2015) indicated that NAA 40 ppm was found effective in increasing number of fruits per tree (62.44), fruit length $(8.66 \mathrm{~cm})$, fruit diameter $(8.71 \mathrm{~cm})$, fruit weight $(262.23 \mathrm{~g})$, fruit volume $(255.44 \mathrm{ml})$, TSS $\left(16.76^{\circ} \mathrm{B}\right)$, total sugars $(15.58 \%)$, reducing sugars $(13.83 \%)$, non-reducing sugars $(1.75 \%)$ against control in the pomegranate cv. Bhagwa.

Rokaya et al., (2016) revealed that the fruits treated with $\mathrm{GA}_{3}$ at $20 \mathrm{ppm}$ retained higher fruit weight (128.6 g), more firmness (3.54 $\mathrm{kg} / \mathrm{cm} 2)$, better juice recovery $(57.75 \%)$, and greater TSS/acid ratio (21.24). Lal and Das (2017) revealed that 50 ppm $\mathrm{GA}_{3}$ was found effective in increasing the yield (37.13 $\mathrm{kg} /$ plant), pulp weight (173 g), Juice content $(63.17 \mathrm{cc})$, TSS $\left(12.50{ }^{0} \mathrm{Brix}\right)$, ascorbic acid (135.30 mg/100gm), total sugar (10.13\%), seed weight (6.67 gm) and sugar-acid ratio (33.13) in cv. Allahabad safeda.

Detailed knowledge of the mechanism of action and advance use of existing bioregulators will not only aid the search for new products, but will be useful in predicting possible secondary effects of potentially market-able compounds in terms of their effects on the environment. The exogenous application of bio-regulators might, therefore, act as a powerful tool not only for enhancing the growth, productivity, quality of fruits but also in combating the ill effects generated by various biotic and abiotic stresses in plants in the near future. There by aiding to enhance potential crop yield and alleviating hunger and malnutrition in the ever-increasing human population of the world. Future research needs, therefore, require a better understanding of the mechanism responsible for developmental processes in plants at the cellular and molecular levels, and a more comprehensive description of the specificity of bioregulators in mediating key biochemical steps.

\section{References}

Adams, P.A., Montague, M. J., Tepfer, M., Rayle, D. L., Ikuma, H., Kaufman, P. B. 1975. Effect of gibberellic acid on the plasticity and elasticity of Avena stem segments. Plant Physiology, 56:757760.

Ahmad, S., Singh, Z., Khan, A.S. and Iqbal, Z. 2013. Pre-harvest application of salicylic acid maintain the rind textural properties and reduce fruit rot and chilling injury of sweet orange during cold storage. Pakistan Journal of Agricultural Science, 50(4): 559-569.

Amiri, N. A, Kangarshani, A. A. and Arzani, K. 2012. Reducing of citrus losses by spraying of synthetic auxins. International Journal of Agriculture and Crop Sciences, 4(22): 1720-1724.

Anawal, V. V., Narayanaswamy, P. and Ekabote, S. D. 2015. Effects of Plant Growth Regulators on Fruit Set and Yield of Pomegranate Cv. Bhagwa. Internatoinal Journal of Scientific Research, 4(9). 
Ashraf, M. Y., Asshraf, M., Akhtar, M., Mahmood, K. and Saleem, M. 2013. Improvement in yield, quality and reduction in fruit drop in Kinnow (Citrus reticulata Blanco.) by exogenous application of plant growth regulators, potassium and zinc. Pakistan Journal of Botany, 45(SI): 433-440.

Bagel, B. S., Tiwari, R. and Gupta, N. 2004. Effect of cultar and NAA on flowering and fruiting of mango (Mangifera indica L.) cv. LANGRA. South Indian J. Hort., 52(1-6): 302-304.

Banghel, B. S. and Tiwari, R. 2003. Individual and integrated effect of urea and NAA on flowering and fruiting of mango (Mengifera indica L.). South Indian Horticulture, 51(1- 6): 1-6.

Brahmchari, V.S., Mandal, A.K., Kumar, R., Rani, R. 1995. Effect of growth substance on fruit-set and physicochemical characteristics of 'Sardar' guava (Psidium guajava L.). Recent Hort, 2(2):127-131.

Brar, J. S. 2010. Influence of paclobutrazol and ethephon on vegetative growth of guava (Psidium guajava L.) plants at different spacing. Not. Sci. Biol., 2(3): 110-113.

Brenner, M. L, Cheikh, N. 1995. The role of hormones in photosynthate partitioning and seed filling. In: Davies PJ (ed), Plant Hormones: Physiology, Biochemistry and Molecular Biology, Kluwer Academic Publishers, Dordrecht, 649-670.

Choudhary, H. D., Jain, M. C., Sharma, M. K. and Bhatnagar, P. 2013. Effect of plant growth regulators on growth and yield of nagpur mandarin (Citrus reticulate Blanco.). The Asian Journal of Horticulture, 8(2): 746-750.

Eel Kim, M. Y., Ho Kim, Y., Kho, C. M, Sang, O. 2003. Effects of foliar application of GA3 on flowering and fruit quality of very early-maturing satsuma mandarin. Korean Journal of Horticultural Science and Technology, 21(2): 110-113.

Ghawade, S. M., Tayde, G. S., Dadmal, S. M and Taral, B. W. 2002. Quality of Nagpur mandarin fruits as influenced by location on the tree. Agricultural Science Digest, 22(1): 55- 56.

Ghora, Y., Vasilakakis, M. and Stavroulakis, G. 2000. Effect of growth retardants (CCC, daminozide \& Paclobutrazol) on growth and development of red raspberries cv. 'Autumn Bliss' cultivated under plastic greenhouse condition in China-crete, Greece. Acta Horticulturae, 513:453-458.

Ghosh, S. N., Bera, B. and Roy, S. 2012. Influence of plant growth regulators on fruit production of sweet orange. Journal of Crop and Weed, 8(2): 83-85.

Goswami, J. D., Patel, N. M., Bhadauria, H. S and Wankhade, V. R. 2013. To study the effect of plant growth regulators on quality traits of pomegranate $\mathrm{cv}$. SINDURI. The Asian Journal of Horticulture, 8(1): 361-363.

Greenberg, K. I., Fainzack, M., Egozi, Y. and Giladi, B. 2006. Effect of Auxins sprays on yield, fruit size, fruit splitting and the incidence of creasing of 'Nova' mandarin. Acta Horticulturae, 727.

Harhash, M. M, and Al-Obeed, R. S. 2007. Effect of naphthalene acetic acid on yield and fruit quality of Barhee and Shahl Date palm cultivars. Assiut Journal of Agricultural Sciences, 38(2):63-73.

Ingle, H. V, Rathod, N. G, Patil, D. R. 2001. Effect of growth regulators and mulching on yield and quality of Nagpur mandarin. Annals Journal of Plant Physiology, 15(1): 85-88.

Iqbal, M., Khan, M. Q., Jalal-ud-Din Khalid and Rehman, M. 2009. Effect of foliar application of NAA on fruit drop, yield and physico-chemical characteristics of 
guava (Psidium guajava L.) red flesh cultivar. Journal of Agricultural Research, 47(3): 259-269.

Kacha, H. L, Viradia, R. R, Leva, H. M, Jat, G and Tank, A. K. 2012. Effect of NAA.GA 3 and ethrel on yield and quality of phalsa under SouthSaurashtra condition. The Asian Journal of Horticulture, 7(2): 242-245.

Khalid, S., Malik, A. U., Khan, A. S. and Jamil, A.2012. Influence of exogenous applications of plant growth regulators on fruit quality of Young 'Kinnow' Mandarin (Citrus nobilis $\times$ C. deliciosa) Trees. International Journal of Agriculture and Biology, 14(2): 229234.

Kher, R., Bhat, S. and Wali, V. K. 2005. Effect of application of GA3, NAA and CCC on physico-chemical characteristics of guava cv. Sardar. Haryana Journal of Horticultural Sciences, 34 (1-2): 31-32.

Kumar, R., Bakshi, M. and Singh, D. B. 2012. Influence of plant growth regulators on growth, yield and quality of strawberry under U.P. sub tropics. Asian Journal of Horticulture, 7(2): 434-436.

Lal, N. and Das, R. P. 2017.Effect of Plant Growth Regulators on Yield and Quality of Guava (Psidium guajava L.) cv. Allahabad Safeda. International Journal of Current Microbiology and Applied Sciences, 6(5): 857-863.

Lawes, G.S. and Woolley, D.J. 2001. The commercial use of plant growth regulators to regulate fruit development. Acta Hort., 553: 149-150.

Medeiros, E. C. de., Siqueira, D. L. de., Salomao, L. C. C., Neves, J. C. L, and Pereira, W. E. 2000. Use of 2,4-D and $\mathrm{GA}_{3}$ to control 'Hamlin' orange fruit drop. Revista Ceres Journal Arti, 47(271): 287-301.

Modesto, J. C., Rodrigues, J. D., Ono, E. O., Habermann, G. 2006. Application of gibberelic acid (GA3) on pre-harvest of 'Ponkan' mandarin (Citrus reticulata Blanco) fruit. Acta Scientiarum Agronomy, 28(1): 37-40.

Murti, G. S. R., Upreti, K. K., Kurian, R. M. and Reddy, Y. T. N. 2001 Paclobutrazol modifies tree vigour and flowering in mango cv. 'Alphonso'. Indian Journal of Plant Physiology, 6(4): 355-360.

Nawaz, M. A., Ahmad, W., Ahmad, S. and Khan, M. M. 2008. Role of growth regulators on preharvest fruit drop, yield and quality in Kinnow mandarin. Pakistan Journal of Botany, 40(5): 1971-1981.

Notodimedjo, S. 2000.Effect of $\mathrm{GA}_{3}$, NAA and CPPU on fruit retention, yield and quality of mango (cv. ARUMANIS) in East Java. Acta Hort., 509(2): 587-600.

Painkra, P., Singh, R. K. and Prabhakar, H. K. 2012. Effect of plant growth regulators on fruit drop and physico-chemical composition of mango (Mangifera indica L.) cv. Langra. Flora and Fauna (Jhansi). 18(2): 213-216.

Prasad, B., Ray, R. N., Prasad, K. K., Chowdhary, B. M. and Brahmachari, V. S. 2006. Effect of growth regulators on flowering, fruit set and fruit retention in Mango. Journal of Research, Birsa Agricultural University, 18(2): 257-260.

Reddy, P. A. and Prasad, D. M. 2012. Effect of plant growth raguletors on fruit characters and yield of pomegranate (Punica granatum L.) cv. Ganesh. Int. J. P. A. E. Sci. 2(2): 2331-4490.

Rokaya, P. R., Baral, D. R., Gautam, D. M., Shrestha, A. K. and Paudyal, K. P. 2016. Effect of Pre-Harvest Application of Gibberellic Acid on Fruit Quality and Shelf Life of Mandarin (Citrus reticulata Blanco) American Journal of Plant Sciences, (07): 1-7.

Saleem, B. A., Malik, A. U., Pervez, M. A., Khan, A. S, and Khan, M. N. 2008. 
Spring application of growth regulators affects fruit quality of 'Blood Red' sweet orange. Pakistan Journal of Botany, 40(3): 1013-1023.

Sharma, N. and Belsare, C. 2011. Effect of plant bio-regulators and nutrients on fruit cracking and quality in pomegranate (Punica granatum L.) 'G137'. Acta Hort., 890 (1): 345-352.

Shinde, B. N, Pawer, B. R, and Kalalbandi, D. B. B. M. 2008. Effect of chemicals and growth regulators on physical characters of Parbhani-Bhushan mango. Karnataka Journal of Agricultural Sciences, 21(2): 318-319.

Singh, R., Godara, N. R. and Dahiya, S. S. 2001. Responses of foliar application of growth regulators and nutrients in ber cv. Umran. Haryana Journal of Horticultural Science, 30(3-4): 161164.

Suleman, M., Sharma, J.R., Kumar, R., Pal, R. and Singh, S. 2006. Effect of different chemicals on cropping pattern and quality of guava cv. SARDAR. Haryana J. Hort. Sci., 35(4): 226-227.

Vijayalakshmi, D. and Srinivasan, P.S. 2002. Impact of chemicals and growth regulators on induction of flowering in off year mango cv. ALPHONSO. Orissa J. Hort., 30(2):32-34.

Yadav, S. J., Bhatia, S. K., Godara, R. K, and Rana, G. S.2001. Effect of growth regulators on the yield and quality of winter season guava cv. 'L-49'. Haryana Journal of Horticultural Sciences, 30(1-2): 1-2.

Ye-mao, Chai Qing, Zhang Lin Tian, Chun-Li Li Yu, Xing Ling Qin, Yuan-Yue Shen 2013. Brassinosteroid is involved in strawberry fruit ripening. Growth Regulation, 69(1): 63-69.

Yeshayahu, M., Greenberg, J., Beni, Y., Cadmon, E. and Talmor, Z.2001. Increasing fruit size of 'Myovaze' Satsuma mandarin by spray with plant growth regulators. Alon Hanotea, 55(5): 205-207.

\section{How to cite this article:}

Shilpy Kumari, Parshant Bakshi, Akash Sharma, V.K. Wali, Amit Jasrotia and Simrandeep Kour. 2018. Use of Plant Growth Regulators for Improving Fruit Production in Sub Tropical Crops. Int.J.Curr.Microbiol.App.Sci. 7(03): 659-668.

doi: https://doi.org/10.20546/ijcmas.2018.703.077 